\title{
New companies' DNA: the heritage of the past industrial revolutions in digital transformation
}

\author{
Elisa Martina Martinelli ${ }^{1}$ D $\cdot$ Maria Cristina Farioli ${ }^{1} \cdot$ Annalisa Tunisini $^{1}$
}

Accepted: 21 October 2020 / Published online: 9 November 2020

(c) The Author(s) 2020

\begin{abstract}
This paper debates the ongoing processes of digital transformation enhanced by the 4th industrial revolution in successful companies which have a long time business history and an international presence. The aim is analyzing how what they have experienced and learned in the 2 nd and 3rd industrial revolutions represents key elements that have shaped their DNA and continue to inspire their transformation to the point that the gradual radical change concept is preferred to the concept of disruption. Such learning processes are primary values to transfer in companies' digital transformation in order to implement it efficiently and effectively creating new opportunities at an international level. The paper leverages on an explorative research based on the empirical setting of three international Italian manufacturing companies that have experienced challenges of the 2nd, 3rd and are now facing an important digital transformation process in a worldwide landscape. A qualitative constructive multiple case research design is conducted to evaluate the conceptual model and some considerations emerged from the analysis. The paper also benefits from 30 years of experience of one of the Authors as Business Development Director of big multinational companies accompanying many enterprises during their digital transformation. This study presents an interpretative framework that provides an exploration of main heritages coming from the past industrial revolutions according to three aspects: business drivers, supply view and entrepreneurial model. The emerged evidences can be taken as lessons by international manufacturing companies in order to implement digital transformation enhancing their international competitiveness.
\end{abstract}

Keywords Internationalization · Digital transformation · Industrial revolution · Italian manufacturing companies $\cdot$ SMEs $\cdot$ Gradual radical change

Elisa Martina Martinelli

elisamartina.martinelli@unicatt.it

Extended author information available on the last page of the article 


\section{Introduction}

In the last few years, both academics and practitioners have underscored that the disruptive power of digital technologies sub-stands to a new industrial revolution-the so-called 4th industrial revolution - that generates a radical transformation in the market and more generally in the economy (Anderson 2012; Berger 2014; Brynjolfsson and McAfee 2016). The adoption and integration of digital technologies into all areas of business changes the way companies create and deliver value to the customers. By leveraging new technologies, businesses aim to generate new customer value propositions or transform their operating models by developing a new portfolio of capabilities to be flexible and responsive to fastchanging customer requirements (Berman 2012). The exploitation of digital technologies affects large parts of companies and even goes beyond their borders, by impacting products, business processes, sales channels, and supply chains (Matt et al. 2015). Thus, a digital transformation is required for long-standing companies that want to stay abreast of the increasingly aggressive international competitiveness represented by digital disruptors. Consequently, digital disruption is necessary for companies that need to shift their mind-set by thinking and acting "disruptively" in order to drive radical change to best meet the future needs of their consumers at the international level (McQuivey and Bernoff 2013; Downes and Nunes 2015). This is a challenge for Italian manufacturing companies, especially those representing the "Made in Italy" label born during the 2nd industrial revolution and historically characterized by a strong entrepreneurial mindset, strategic and organizational flexibility, product excellence, and manufacturing capabilities. Indeed, "the general appreciation of Italian products which have always been associated with superior quality, extreme attention to detail, elegance and a long-established tradition in manufacturing" and the recognition of these aspects by the international landscape are among the key elements that constitute the DNA of Italian manufacturing excellence (Madeinitaly.org 2019). In this research, we focus on Italian manufacturing companies as an empirical setting, but we can suppose that our considerations could also be applied to manufacturing companies in other countries. In fact, if in this study the attention is concentrated on the specific label "Made in Italy" that help to define the DNA of Italian manufacturing companies, abroad companies leverage on other specific assets.

This paper analyses the ongoing processes of digital transformation enhanced by the 4th industrial revolution in small and medium enterprises (SMEs), which have a long business history and an international presence, in order to analyze how what they experienced and learned in the 2nd and 3rd industrial revolutions represents key elements that have shaped their DNA and continue to inspire their transformation. We use the term "DNA" to refer to the fact that companies' original key features and business identities have supported and driven their development and international competitiveness while continuing to play a key role in their development processes, even if such DNA is to be shaped in order to survive and face the changing business environment. The companies' abilities to continuously reshape their DNA can be partly theoretically referred to what literature 
underscores when it puts into evidence the role played by path dependency and dynamic capabilities in supporting companies' strategies (Teece et al. 1997; Felin and Foss 2009; Vergne and Durand 2011). Today's companies are not the result of a totally destructive process, but of a reshaping of their capabilities, routines, and ways of being. As Baskin $(1995,2012)$ affirmed, to deal with new technologies, aggressive competition, and extremely demanding customers, companies need to adapt or die, and their DNA is a key point of reference, but it must be shaped. Indeed, Kransdorff (2017) wrote that "individuals or organizations seldom learn from experience unless the experience is assessed and then assigned its own meaning" in terms of the organization's own goals, aims, ambitions and expectations. The use of the DNA metaphor has been adopted not only by academics, but even by managers as evident in their business jargon in terms of what makes a company unique (Bonchek 2016; IGS Connect 2017; Forbes 2018).

The goal of this paper can be summed up in the main research question concerning how international manufacturing SMEs are successfully facing the digital transformation by leveraging the memory/heritage and exploitation of the main lessons acquired through the 2 nd and especially the 3 rd industrial revolutions. In order to answer to this question, we present an interpretative framework that sustains the point that such learning processes are primary values to transfer in the companies' digital transformation in order to implement it efficiently and effectively, creating new opportunities for SMEs at an international level. On one hand, conceptually we want to sustain the idea that digital transformation can amplify the development of new opportunities, especially in a worldwide context. On the other hand, we think that this can occur provided that the companies leverage the lessons of the previous transformation processes. Unlike those scholars who demand companies' digital disruption, stressing the need for a strong discontinuity with the past, we emphasize that international manufacturing SMEs should proceed using a gradual radical change approach that improves transformation processes already started, especially during the 3rd industrial revolution.

In order to start our discussion, we introduce a conceptual model to focus in detail on the main issues of the 2nd and 3rd industrial revolutions according to three main elements-namely, business drivers, the supply view, and the entrepreneurial model - and to highlight briefly the same elements of the 4th industrial revolution. A qualitative constructive multiple case research design is conducted to evaluate more deeply the conceptual model using an analysis of three international manufacturing SMEs that established their businesses in Italy at least 50 years ago and have now become involved in the digital transformation process. Through these case studies, we develop a more detailed comprehension of the characteristics and challenges that the company will face as it now approaches an international context and transforms its business drivers, supply view, and entrepreneurial model in the 4th industrial revolution. We thus depict an interpretative framework and some considerations that highlight the major issues to consider in such a transformation that incorporate and leverage transformation processes initiated in the past.

The paper is structured as follows. In Sect. 2, we depict the companies in the 2nd, 3rd, and 4th industrial revolutions with regard to their business drivers, supply view, and entrepreneurial model through the literature review. In Sect. 3, we present the 
methodology and analyze the three international case studies. Section 4 provides a detailed analysis of the business drivers, supply view, and the entrepreneurial model that characterizes international companies facing the digital transformation using an interpretative framework. The goal is to highlight the relevance of getting the most from past lessons and adopt a gradual approach to being an international key player in the 4th industrial revolution. Finally, Sect. 5 concludes the paper.

\section{Theoretical background}

Digital transformation, digital disruption, and the 4th industrial revolution are definitions commonly recognized and debated in recent years (Schwab 2017). Even if no consolidated literature on the topic exists yet, the study of new digital technologies and their impact on companies, markets, and businesses are at the center of scholars' studies in all types of disciplines (Uhl and Gollenia 2014; Beltrametti et al. 2017). Management scholars in particular have vigorously debated the need for companies to transform and grow, leveraging new business models that let them keep and develop their international competitiveness in the new ecosystems (Kagermann 2015).

If we can agree upon the fact that new technologies have a disruptive power on the traditional way of doing business, we are also convinced that an international company can effectively and positively face the ongoing transformation if it is also able to accept a few important lessons from past industrial revolutions.

Digital transformation is not necessary in any company at the same level of involvement and impact; however, no companies can avoid taking into account how changing affects their business context because of digitalization. It is important to recognize that the new ecosystems can be confronted using the heritage of past management and organizational issues not as a burden, but as learning opportunities to be exploited as potential factors for differentiation.

To a large extent, when the literature discusses digital technologies (Herbert 2017), the focus is on the 4th industrial revolution while the previous ones are always analyzed in contrast. Past contributions focus on discontinuities, especially technological ones, and affirm that those discontinuities initiated by already existing firms can decrease the level of environmental turbulence (Tushman and Anderson 1986; Siebel 2019). In particular, studies have demonstrated the different stages in the evolution of a successful enterprise according to the changing character of an innovation (Abernathy and Utterback 1978). In this research, we consider this literature and assume that the 4th industrial revolution originates from the principles and values generated by the 2 nd and, especially, 3rd industrial revolutions, linked strictly to the evolution of innovations and technologies. This is a key element for the company to understand in order to implement an effective transformation. In our research, we talk about "gradual radical change" due to the long-term strategy adopted by the manufacturing enterprises analyzed and the characteristics of the technological innovation involved (Gallivan et al. 1994). Therefore, we depict the main aspects that predominantly characterize the 2nd and 3rd industrial revolutions through the analysis of three key distinguishing elements: business drivers, 


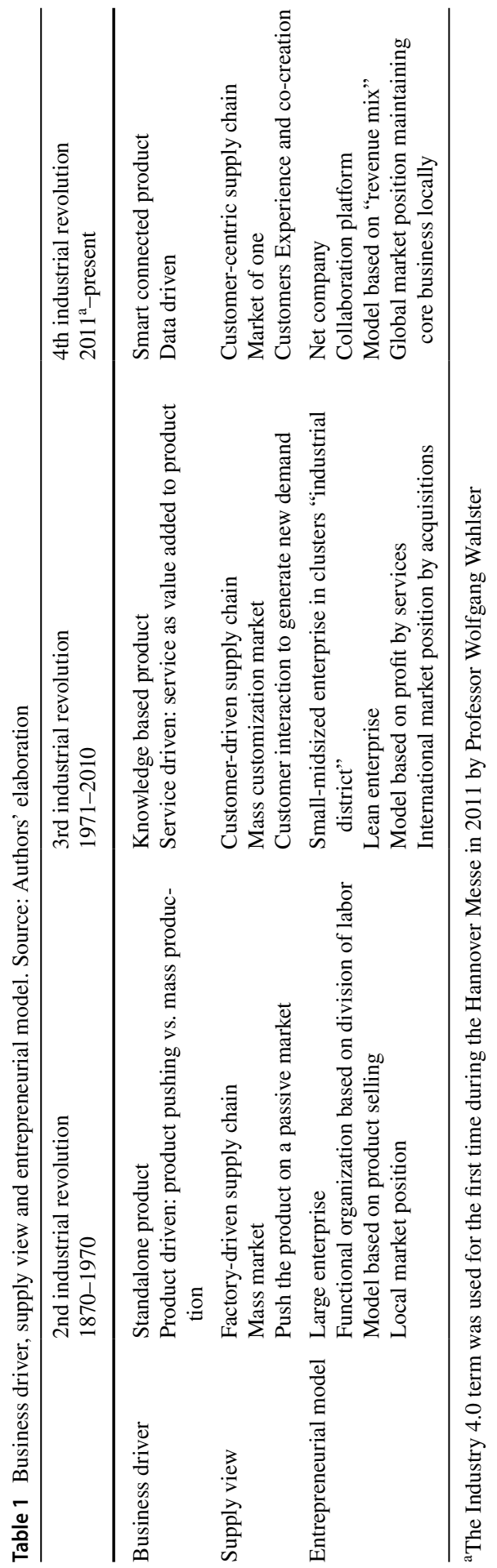


supply view, and entrepreneurial model (Table 1). These three elements come from an adaptation of Varaldo et al.'s (2009) study "An emergent treasure. Italian midsized firms of the global age" and research conducted by the Società Italiana Marketing in 2006, in which the three dimensions emerge as a basis of Italian mid-sized dynamic firms for their market success - namely, competitive, relational, and entrepreneurial dimensions, respectively. This previous research was then implemented and published by Springer Science \& Business Media in a book entitled "Mid-sized manufacturing companies: The new driver of Italian competitiveness" (Coltorti et al. 2013). The business driver refers to the companies' offerings and the key factors that make these offerings competitive, thereby affecting business results. Supply view concerns the company's approach to the market and its value proposition (driver, market, and type of demand). The entrepreneurial model refers to distinguishing organizational elements of the enterprise as the type of organization model, company dimension, and business model.

In terms of the analysis of the business drivers, the 4th industrial revolution is characterized by smart connected products. According to Porter and Heppelmann's (2014) paper, this new business driver is a new typology of product that is constituted by three main elements: physical, smart, and connectivity components. The first is related to mechanical and electrical parts; the second refers to software, sensors, data storage, and digital interface; and the last one considers all elements that allow for a connection between the product and cloud. Smart connected products need a "technology stack," which refers to an infrastructure for information and data sharing. It is formed by the software and hardware components of the product, connectivity, cloud, identity, and security tools, integrating external information sources and enterprise business systems (Porter and Heppelmann 2014). Thanks to their intrinsic features, smart connected products become unique. In fact, these new products increase their level of capabilities and activities by monitoring themselves and their environments, through optimization using advanced algorithms, and through users' direct control. These specific characteristics focus the attention on the data. In the 4th industrial revolution, data are considered the core of the company. Data are delivered in real time, characterized by an unprecedented variety and volume. This complexity is due to activities that are streamlined in a number of new ways. In fact, the collection of internal and external data and structured and unstructured data-namely, data coming from the main company and data regarding the business environment (e.g., other actors, weather), respectively-has repercussions in terms of integration and connectivity. The insights generated by data can help businesses, customers and partners optimize product performance. The promise of real-time enterprises - organizations that can respond to need and demand instantaneouslyis finally becoming a reality thanks to the Internet of Things (IoT). In the 4th revolution, it is now machines and devices that are communicating, continuously and in ever greater numbers. This is a gradual radical change compared to the 3 rd industrial revolution, which covers a very extensive period from the late 1970s to a few years ago (if not still today for many companies), and it was centered around information technology. The 3rd industrial revolution was based on the usage of electronics and information technology to automate production increases. The development of information and communications technology (ICT), robotics, and flexible automation 
technologies [computer integrated manufacturing (CIM); computer-aided design (CAD); computer-aided engineering (CAE); flexible manufacturing systems (FMS); and electronic data interchange (EDI)] made possible a rapid diffusion and sharing of knowledge within the company and its partners. The service and the knowledge incorporated into the product made differentiation elements in an economy scenario increasingly challenging (Sanchez and Mahoney 1996; Zack 1999). The change is even more evident if related to the 2 nd industrial revolution, characterized by rigid standardized technologies, mass production, and the "era" of the large business enterprise. The focus was on the standalone standardized product and on the concept that the standardization of products and processes was able to generate efficiency thanks to the economies of scale at both the production and the whole organizational level (Womack et al. 1990).

Regarding the supply view, during the 4th industrial revolution, powerful new data available to manufacturers together with new configurations and capabilities of smart connected products have restructured the supply view. In fact, in order to compete globally, manufacturers have to be able to face the enormous variety and variability that have emerged. Volatility, dynamism, and turbulence are distinctive features of the new business environment (Christopher 2016). Increasingly demanding customers require high-quality and ad-hoc products or services at low prices. Therefore, suppliers must seek to satisfy customers' needs through well-suited solutions. For this reason, the customers are heavily involved in the activities of the manufacturer and exploit the opportunities arising from increasing technological power. According to Potter et al. (2015), customers today can choose how, when, and where they want to get their products, reorienting the supply view toward a customer-centric orientation. This is particularly evident with the arising usage of specific technologies that allow the co-creation by final customers. The concept of a one-sizefits-all solution for products and services has been overcome (Rogers et al. 2016). Customers' preferences are moving toward a market-of-one (Stevens and Johnson 2016), where customers and partners become co-producers (Syam and Pazgal 2013; Bogers et al. 2016). The final result delivered is no longer simply an output, but an outcome formed by a mixed solution of services and products (Christopher 2016). The gradual radical change is particularly evident according to the increasing attention on customers' understanding. In fact, whereas the 2 nd industrial revolution was characterized by a first attempt to satisfy the final customer through the delivery a product even if by a factory-driven supply chain and stand-alone standardized products, the 3rd industrial revolution was focused on demand generation and making a rapid reaction to customers' demand possible by means of lean supply chains (Lamming 1993). This new approach modified the orientation toward the market, and the traditional manufacturing company used to operate according to a customer who became the final destination and activator of all the development and delivery processes throughout the whole supply chain, making mass customization possible (Baldwin and Clark 1997). A greater dialogue and interaction with the demanding customer and the increase in variety and variability of the product offerings affirmed the customer-driven perspective to supply chain management (Hines 2012).

Considering the third aspect, the entrepreneurial model, during the 4th industrial revolution, competition has been reshaped and the traditional industry boundaries 
have dropped and converged. The networked and interconnected organization could overcome traditional business boundaries. In addition, boundaries among the company's functions change. The manufacturing companies dealing with new smart and interconnected products refresh traditional functions and create new forms of collaboration and new units. As Porter and Heppelmann (2015) effectively illustrated, a transformation in the role and responsibilities of many key functions significantly changes the logistics function in line with a continuous monitoring process of inputs/outputs coming from smart connected products. Product development units have started to require a high level of software and hardware knowledge toward interdisciplinary system engineering. The manufacturing function has been completely restructured, where an automated and complex cloud-based infrastructure is the central element. The need to provide full transparency about customers' needs leads to the reshaping of the marketing and sales units to improve the constant alignment with smart connected products while the after-sales services have shifted from reactive services to preventive and proactive ones due to the ongoing revision and modification of actual products that can be remotely monitored. Simultaneously, with these recent transformations in each of the business units, new forms of collaboration and new functions have emerged as a unified data organization, leading to the need for new roles (e.g., chief data officer) able to gather and analyze data generating more insights for organizations. The requirement for IT in the development of smart connected products is essential. New functions that manage the cloud platforms inherent in new these technologies have become necessary. Finally, customer success management is specifically created in order to ensure that the customer always gains the maximum value from the product. Digital transformation is about sweeping change. It changes everything about how products are designed, manufactured, sold, delivered, and serviced, and it forces CEOs to rethink how companies execute, with new business processes, management practices and information systems as well as everything about the nature of customer relationships (Siebel 2018). Gathering the lessons learned from globalization, companies have come to understand that protecting their own core businesses locally can improve their competitive advantages and brand consideration. The gradual radical change to the 4th industrial revolution is particularly evident when compared to the 2 nd and 3rd industrial revolutions. In fact, in the previous periods, which were characterized by large companies and scale economies, where companies were mainly focused on production processes and on product pushing in local markets, there was a change toward the latter, identified by lean organizations and small to midsized enterprises able to face the market unpredictability thanks to the flexibility (Varaldo and Ferrucci 1996) and knowledge-sharing achieved with network partners (Achrol and Kotler 1999).

\section{Research methodology}

In this section, research design, motivation for selection of the case studies, data collection and analysis are highlighted. 


\subsection{Research design}

The paper debates on the ongoing processes of digital transformation in international manufacturing SMEs that have a long time business history. In particular, the study wants to explore how past industrial revolutions represent important source of learning for companies that implement a digital transformation. In order to answer to this question, a qualitative constructive multiple case research is conducted. Multiple case approach (Ellram 1996; Yin 2013) is particular suitable in this research for two main reasons: the attempt is to generate new theory (Yin 1989; Fawcett et al. 2014; Ridder 2017) and this methodology allows "an empirical inquiry that investigates a contemporary phenomenon within its real-life context; when the boundaries between phenomenon and context are not clearly evident; in which multiple sources of evidence are used" (Yin 1984, p. 23). The sample is constituted by three Italian manufacturing companies through a purposive selection. In multiple case approach, the number of selected companies is small in order to allow a depth analysis and discussion on "how" and "why" of each case (Lillis and Mundy 2005).

According to the main aim and willingness of the study to development a framework, a focus should be devoted to reliability and validity of the research process (Yin 2003). The internal validity (logical validity) is supported by a conceptual model based on three key elements: business drivers, supply view and entrepreneurial model that come from an adaptation of the work of Varaldo et al. (2009), then implemented and published by Springer Science \& Business Media in a book entitled: "Mid-sized manufacturing companies: The new driver of Italian competitiveness" (Coltorti et al. 2013). Construct validity (quality of the conceptualization) is sustained by explanation of data collection and analysis and data triangulation trough extensive desk research, primary data collection and meeting with experts. External validity (generalizability) is strength by multiple case studies analysis and details on case study context. Finally, reliability (correctness of operational and research procedures) is highlight by the usage of case study protocol. All these aspects sustain the methodological rigor of the research process (Cook and Campbell 1979; Yin 1984; Gibbert et al. 2008).

\subsection{Case selection}

The qualitative constructive multiple case research is conducted by selecting three Italian manufacturing companies: Biesse Group, Bianchi SpA, and Irca SpA of Zoppas Industries $\mathrm{SpA}$. In this research we focus the attention on Italian manufacturing companies, but it can be supposed that our considerations could be applied also to manufacturing companies of other countries. As underlined by a research presented by Gabriele Barbaresco during the 2nd Conference on "Management and Marketing in the Digital Age: Digital Transformation in Italian SMEs" hold at the Catholic University of the Sacred Heart in Milan on the 8 of February 2020 (Mediobanca 2020), the Italian SMEs declared that the adoption of solutions connected to Industry 4.0 is for $42.3 \%$ of interviewees a strategic necessity, for the other companies the integration of these typologies of innovation is considered only as an advantage in 
order to gain tax bonus. In addition, by the presented study, emerged that $65.9 \%$ of interviewed SMEs didn't integrate innovative solutions for the willingness to privilege other investments, $22 \%$ declared a negative trade off cost-benefit and $12.1 \%$ highlighted a paucity of human resources. For Italian SMEs that adopted new solutions, $37.2 \%$ invested in machineries, $23.3 \%$ in machineries and processes, $3.1 \%$ only in processes, $25,3 \%$ are evaluating their implementation, $11.2 \%$ didn't adopt them. Due to the increasing attention on the analysis of Italian manufacturing companies operating in the Industry 4.0 context, we decided to chose 3 case studies according to the intention of achieving a diversity of responses based on characteristics or attributes that are important to the evaluation (Patton 1990). The including criteria are: (a) Italian born companies, (b) business history old of at least 50 years, (c) manufacturing companies, (d) successful digital transformation process, (e) market leadership, (f) significant international presence (Table 2).

\subsection{Data collection and analysis}

The analysis was initially based on secondary data that involved an extensive desk research (study of conference proceedings, papers, reports, organizational chart, website, etc.). Then, primary data have been collected by direct interviews to innovation managers involved in the three international companies' transformation processes. We conducted 8 semi-structured using a pre-designed guideline. They lasted about 60 min and were collected between November 2018 and March 2019. In addition, all collected data have been validated, expanded and extensively interpreted by one of the Authors of the paper, who has 30 years of experience as Business Development Director of big multinational company accompanying many enterprises in their automation during the nineties and digitalization in the last decade.

In the following paragraphs, we analyze the data, walking through the history of three selected companies in order to, then, discuss our assumption in paragraph 3.5.

\subsubsection{Biesse Group}

Biesse was founded in Pesaro in 1969 to design, manufacture, and distribute woodworking machines (Biesse Group 2018). The first boring machines were standalone standardized machines making repetitive processes, allowing only the change of the electrospindles. The focus of the entrepreneur still governing Biesse Group, now listed in the Italian stock exchange, was on the quality of the production and performance of the single machineries that were then sold to the growing industrialized furniture industry. The latter was based on various small and midsized manufacturing companies producing on their part standardized components or final furniture products.

Production was quite totally controlled by the company that also owned the production of the electrospindles. In the specific business based on the boring machinery, Biesse acquired a strong market positioning based on the quality of the single specialized machinery that was highly competitive for the price. In 1978, Logic Control, the first numeric control wood-drilling machine, was launched; in 1983, 


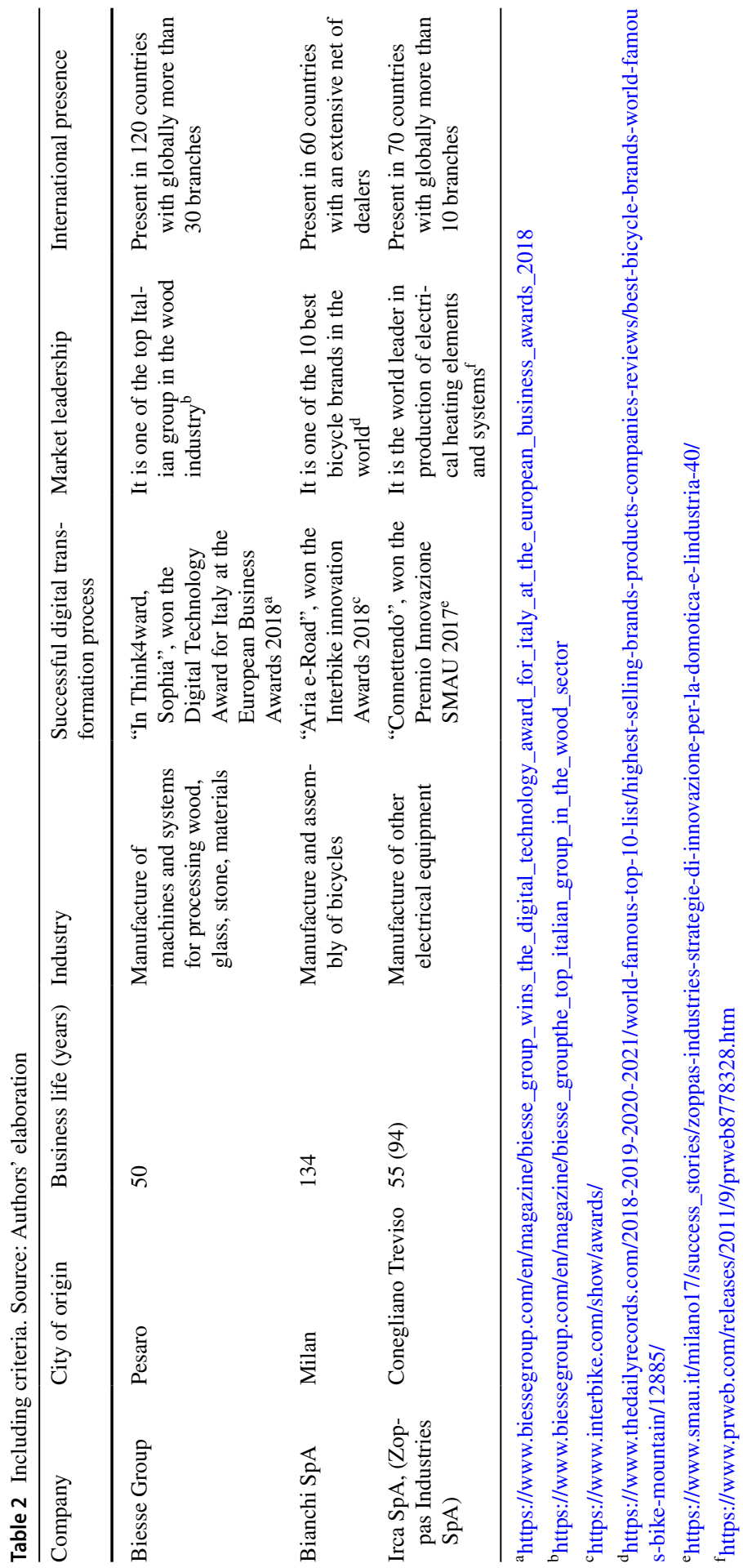


Rover, the first numeric control wood-processing center, entered the market (Biesse Group 2012). These were the first machines to incorporate the new flexible technologies and, in 1991, a Mechatronics business unit was established to design, manufacture, and distribute electromechanical components. In 1994, a Biesse Systems unit was founded to design and manufacture integrated production lines and systems. The growth of the company continued over the years through the acquisition of a number of small companies specializing in different phases of the woodworking process as well as those of glass, stone marble, and plastic. Simultaneously, the group expanded internationally and became the third largest group worldwide. From the 1980s until a few years ago, Biesse Group has been able to combine continuous innovation with both external partnerships and acquisitions and with internal R\&D processes, searching for continuous innovation and cost efficiency. The latter was reached by an accurate strategy of product modularity in both the design and production processes. The company managed to standardize the many different functions of the most important components to gain the economies of scale on the production of repetitive modules. Adaptation to the single customer and differentiation were achieved through the varied combination of the different modules in customized product solutions enriched with a set of additional services: set up, training, maintenance, repair, upgraded modules, and so on. The attention to the single customer needs was also proved by the foundation of Biesse Systems. During the refocusing to a more complex offering, the company also revised the structure of its supply chain and the relationship with suppliers that were increasingly selected and rated according to their capability to proactively concur to value generation for Biesse's customers.

More recently, since 2015, Biesse Group has gradually exploited the opportunities stemming from the innovation processes, enriching the product (i.e., the machineries and/or production lines) with additional services, functions, and elements - first of all, sensors. Biesse's service technicians constantly monitor machineries' functionalities by the machine and by distance. Data are collected and elaborated on, making it possible to check the functioning of the machines and upgrade them as well as intervene in their maintenance and repair from a distance. Data are collected in large amounts. However, as Paolo Tarchioni (CEO and assistant for innovation at Biesse Group) affirmed during an interview, "a lot is still to be done to intercept and select the right data to collect and process them in a way that make it possible to improve the service given to our clients." Thanks to leading-edge architecture, important data useful for the client and for the effective functioning of the machinery are stored and processed by the client itself. Data are transferred to a cloud system only when they refer to information Biesse needs to receive and process. Linked to complex themes such as cybersecurity, this solution helps reduce clients' challenges when transferring their strategic data to cloud systems.

Despite the fact that Biesse has always handled its relationships with clients according to an interactive approach, as key clients always concurred with Biesse's product improvements and new product development, the key customers' centrality became an essential element after the introduction of flexible automation in the 1990s, when many machines' improvement was made possible by the suggestions given by the lead users. In recent years, Biesse Group has gone a step further when 
relating to the customers to offer them a full experience of multiple advanced services around the technological platform (i.e., the machinery). The most valuable part of Biesse's offering is given by its ability to enter into the analysis of the customer's production and working processes implemented though Biesse's machines. The core value offered to the client is thus data collection and elaboration in order to give suggestions on how to improve the working processes.

As the machineries developed by Biesse can be configured according to different functionalities, sensors, and service levels and considering that the value of the offerings delivered to the client stems from the monitoring and improvement of its manufacturing process thanks to the information and data gathered by the machineries, new business opportunities have been opened to Biesse. First, the company has the possibility to expand in the market by reaching those customers that cannot afford to buy their machineries but can "pay per their use" (Accenture 2018). We can observe a greater democratization in the usage of the advanced solutions offered by Biesse Group as the core value perceived and delivered to the client is not the machinery or the production line itself, but rather the support in the manufacturing process of the client based on the use and not the ownership of the machines. This determines a one-to-one customized offering that is based on the idea to provide solutions to customers' specific needs. A second business opportunity opening up to Biesse is the offering of the data acquired from its machinery to the suppliers of parts and components that, thanks to these data, can improve their products.

As Paolo Tarchioni affirmed, "Biesse started to operate in the Italian market and nowadays registers that, even if Italy is only the $15 \%$ of the total market share, during the last years the local demand has increased extremely thanks to new investments made by companies using woodworking machines, especially related to Industry 4.0 incentives." The business is transforming as described above; the revision of some of Biesse's organizational functions is in process. The focus on providing services around a product platform requires a profound transformation in the capabilities of the salesforce, leading to becoming primarily a consultant providing solutions rather than a seller of products. In addition, from a broader organizational perspective, a transformation is gradually requested in the overall Biesse organizational structure. It was historically based on a matrix structure that now appears to be too rigid. The main goal is to generate small team-based units that share the same customer project and gradually revise the traditional functions.

\subsubsection{Bianchi SpA}

Bianchi, established in 1885 in Via Nirone in Milan, is the world's oldest bike brand (Bianchi SpA 2018). It has been a pioneer of bike performance, technology, and style (Epic Cycles 2018). In 1914, Bianchi produced 45,000 bikes, 1500 motorbikes, and 1000 cars; in 1935, it produced more than 70,000 bicycles and became a leader in the Italian market (BikeType 2018).

Even if nowadays the production focuses only on bikes in all their varieties, until the late 1960s, Bianchi continued to manufacture cars and motorbikes (Cyclist 2015). In 1990, Bianchi Spillo was created as a new typology and generation of bicycles that reshaped the sector. In 1997, Cycleurope A.B. Group, the Swedish 
company of the Grimaldi Group, acquired the Bianchi Group (Bianchi, Legnano, Puch, and Chiorda), becoming a unique network in the two-wheel market. Today, Cycleurope aims to invest in the development of highly advanced products and the internationalization of the Bianchi brand (Bianchi SpA 2018).

The business history of the company is based even on several successes and legends, like Coppi, Pantani, and Gimondi, and 15 Grand Tour wins. Thanks to this complex and heterogeneous heritage, Bianchi produces a wide range of different top-notch racing machines, specifically for long distance races and sportive bikes (Epic Cycles 2018). The distinguishing symbol of Bianchi's products is the color it uses for its bikes, which is a special blue famous as Celeste Bianchi. It is distributed over all five continents and in more than 60 countries. Internationalization and distribution are key elements of the company's strategy. Bianchi is globally present through Cycleurope sales units and Bianchi distributors, carefully selected from the best ones of each country. The wide range of distributors develop relationships with the customers (dealers) and directly collaborate with Bianchi to analyze the competition and verify the alignment between adopted commercial strategies and consumers' expectations. In order to fulfill this purpose, Bianchi introduced a B2B platform to support its extensive net of dealers, building an easy and effective way for order placement (Bianchi SpA 2018).

Due to its origins, the Italian domestic market still represents an important area of business as both a product tester and turnover, which account for $30 \%$ of the company's total revenues. All the design, conception, engineering, and prototyping activities are located in Treviglio-Bergamo, while the production and some assembling activities are carried out in Southeast Asia by independent firms to help keep costs down, but under the technical control of engineers from Bianchi. Assembling and testing for the top of the range, Bianchi Reparto Corse, are performed in Italy. The factory assembles about 100 bikes per day, with a total annual production of 25,000 bikes. The company with its legendary Bianchi Reparto Corse has also optimized and accelerated the process of innovation through a close collaboration with its professional riders. As the use of data is becoming increasingly relevant in some key activities in order to improve its products, all data are continuously and carefully analyzed by Bianchi engineers through the advanced analytics software. These data come from several activities, such as prototyping and testing where every new bike or update of an existing model is tested by the sponsored athletes, during the training camp, or in competitions where experts are permanently present to collect feedback and level of performance.

Bianchi's success, given by a constant positive trend in sales over the past years, is supported by investments in $\mathrm{R} \& \mathrm{D}$, technology developed internally and externally, as well as innovative materials and the capacity to forecast new trends. As Fabrizio Scalzotto, Bianchi CEO, affirmed in an interview (Bianchi SpA 2019b), "Bianchi has always celebrated its heritage and pursued innovation. At this moment in time, those two values have never been more obvious." This aspect reflects the centralization to local level of the core functions like R\&D, customization, brand management. Countervail vibration-cancelling technology is an example of this strategy, which was developed with NASA as an American patent over 2 years of co-working while Bianchi has the exclusive usage of it in the bicycle industry (Epic 
Cycles 2018). In design, the company leverages CAD software and rapid prototyping machines to create models so it is able to optimize the geometry and improve the design, shape, and engineering of the bikes at the factory. Frames are made from blue resin, which has been produced by a 3D printing machine. The prototyped result is tested in the wind tunnel at the Magny Cours F1 race circuit in France by a team of professional riders, with Laboratorio Tecnologico being the department involved in this process (Cyclist 2015).

In recent years, the company has moved from the mere concept of the cycle product to the experience of cycling. Thus, the Bianchi bike is perfectly aligned with the customer's intended use of it. This is evident by the entrance of the new e-bike and bike fitness range E-ROAD/E-ALLROAD. The Aria e-Road solution is no more a simple bike, but a bike with a long-lasting battery (reaches $200 \mathrm{~km}$ ), with the iWOC system (user interface for battery charge levels) and a smartphone app Ebikemotion able to integrate and monitor numerous data and parameters of the cyclist. These new integrated functions allow users to obtain power management, GPS direction indications, and specific fitness aspects (e.g., use of a cardio band). Another example is Lif-E. Bianchi Magazine (Bianchi SpA 2019b) described it as "Bianchi's Electric Intelligence programme. It's our conceptual playground, where we combine innovation and inspiration to deliver a new type of mobility and a new way of living."

Bianchi faced issues from globalization through a more international organization and production after its acquisition by the European Group. The strategy is not to invest in handmade production, but rather in the Italian brand heritage. This allows for increasing the quantity at a competitive price while controlling the technical aspects, diminishing lead time, improving quality, and increasing the ability to react to market needs. Bianchi operates in its home country, sourcing from cheaper locations by small investments and managing distribution channels.

\subsubsection{Irca SpA}

Irca SpA belongs to Zoppas Industries (ZI) Heating Element Technologies. It is a manufacturing company that operates in a global market supplying the design, manufacturing, and sale of heating elements and systems for domestic and industrial applications. The brand's tagline is "Zoppas li fa e nessuno li distrugge," where the long Italian heritage is founded on strong products that are easy to use (Electrolux Global Brand Licensing 2018).

In 1925, the company Zoppas Ferdinando \& figli s.n.c. was founded as mechanical workshop in Conegliano, Treviso, by Ferdinando Zoppas. During the 2nd industrial revolution, the company started its activity by repairing, not owning, economical wood-burning cookers. It experienced its first success in 1948 with the creation of its own wood-burning and coal-powered cookers.

In the 1950s, employees, production, and sales grew. At the beginning of the 1960s, with the emergence of the production of washing machines, Zoppas became a joint stock company, Ferdinando Zoppas SpA. In 1964, Irca SpA was founded in order to establish a vertical production process of washing and heating systems, and the Stovella - the first Italian dishwasher-was created. In the years of the economic miracle, the company had its greatest expansion in the mass market and it started 
to export its products to the European market while importing know-how from the United States in order to produce defrosting elements.

Simultaneously with the saturation of the market, political events, and the restructuring of the sector, the group was sold to Zanussi of Pordenone, its main competitor. In 1977, mechanical processes were overcome to automate the production processes. In 1984, Zanussi became part of the Swedish multinational Electrolux, and the company was a licensor of its brand, whose production facilities were in Italy. In 1985, the group reorganized itself into strategic business units (SBUs) for internationalization and product range extension. In 1986, a new engineering office was created to support projects for European space and aeronautics programs. Starting in the 1990s, a powerful strategy of geographical expansion led the company to acquire and build production facilities in Germany, Brazil, Romania, Tennessee, Mexico, China, and northern markets. In 2008 the company started operating in the highend American market. 2011 was a year of consolidation, when the group acquired Nova Industries and Prang + Partner AG. The group's division into SBUs was more finely tuned to aim even more precisely at the different market segments and relative applications.

The aim of Irca SpA is to be the market leader in all sectors providing cooperation and co-design to all customers as well as quality, innovation, and time-to-market to suppliers (Zoppas Industries 2018a). ZI uses its Zoppas Lean System methodologies to share competencies and know-how among the entire group. In fact, as Federico Zoppas, general director of ZI, affirmed, "Industry 4.0 is a necessary step in order to be present in innovation processes that are linked not only to the product, but also to the overall process and adoption of new technologies" (Zoppas Industries 2017). It wants to develop new products and new technologies in order to reduce the total production costs, simplify the production flows, and increase the product quality. The Research and Development (R\&D) department is a core feature of ZI, with the main purpose of anticipating market needs under the main scope of continuous research for better solutions (Zoppas Industries 2018b). R\&D focuses on heating element applications in SBUs in order to share synergies among ZI.

The most recent business challenge of Irca SpA is home automation. The company created the Connettendo platform in order to allow B2B companies to connect, control, and generate revenues from service activities for the Internet of Things. This was possible through an agreement between Irca SpA and established technology partners, such as SMC, Eurotech, and Sysdata, as well as start-ups. It therefore adopted the Open Innovation paradigm based on the Liferay IoT Experience solution (SMC and Zoppas Industries 2018). The areas of application for Connettendo are domestic heating and industrial production in the logic of Industry 4.0. It provides device connectivity, a cloud platform, data, and mobile application information that require minimal installation and limited costs to provide advanced custom capabilities for object-based implementations for specific purposes. To manufacturers, it offers supply chain optimization, predictive maintenance, real-time monitoring, and customer profile data for supporting the customization of sales and service processes (01Net 2018). Distributors and installers provide a customer base and knowledge on the installed base, marketing analysis, direct monitoring, and predictive and customer interactions. The end user can use smart home solutions in order to obtain 
data to be used to improve performance, optimize consumption, and plan maintenance; the same data are shared by the entire supply chain, from the plant engineer to the maintenance technician and the plant's distributor. The interest matured by Irca $\mathrm{SpA}$ in the development of a cloud platform able to communicate remotely with its devices is combined with that of managing an innovative after-sales service, which integrates new digital services, to get in touch with end customers (Sysdata 2018).

\subsection{Summary and discussion of case studies' results}

The three case studies are representative examples of successful international manufacturing SMEs that, with their Italian long business history, expanded through the key industrial revolutions, reaching an international presence. The companies have been able to mix tradition and innovation, demonstrating that it is possible to thrive in the 4th industrial revolution by capitalizing on and maintaining the lessons learned from the past in order to deliver value to the increasingly demanding customers at the international level. This is particularly evident when the three cases are rethought under the three aspects presented in Table 1: business driver (stress on standardization and servitization), supply view (focus on product-to-customer centralization) and entrepreneurial model (attention to control and market openness).

According to the first aspect in Table 1, business driver, we can affirm that all three international companies import two key concepts from the past experience: standardization and servitization. For Biesse, thanks to its past heritage, its focus on the standardization of parts and components and on the product customization by the assemblage of the different parts is still at the core of the business. The company invests in product modularity, which has accompanied the increasing automation of the machines, making it possible to achieve mass customization. Bianchi has the same strategy based on components of massively produced bikes at low costs in Southeast Asia that are subsequently assembled and customized in Italy. Irca SpA, through its Connettendo solution, offers manufacturers a modular, secure, scalable, and reliable platform to connect to its products and support the customization of sales and service processes.

The servitization for Biesse is based on its ability to offer machine monitoring, maintenance, update, and development remotely as well as through the elaboration of the data collected and processes by the machines in order to suggest production improvements and innovation to the customer. The core value delivered to the client is not the machinery or the production line in itself, but rather the support in the manufacturing process of the client that is based on the use, not ownership, of the machines. This is also developed by pay-per-use offerings. Meanwhile, Bianchi's implementation of servitization through the integration of an app able to interact with the bike and the rider is the paradigm of the 4th industrial revolution: data coming from the client and/or the objects (bike) can run straight to Bianchi. Bianchi can monitor performance and defects in real-time and send more details for adjustments to its design functions. A similar situation is evident in Irca SpA, where servitization is obtained by the incredibly amount of data (i.e., Big Data) coming from 
the use of the specific new platform. Big Data originates from the customer, who can use smart home solutions to obtain data for improving performance, optimizing consumption, and planning maintenance; it also comes from the plant engineer and is sent to the maintenance technician and even the plant's distributor in a logic of integration between information and services.

Regarding the second aspect, the supply view, international companies have adopted a product-to-customer centralization. The cases offer evidence of a dramatic shift in companies' attention from products to customers. Supply chain performance and customer centricity are a common goal for all three companies discussed, which meet the need of volumes, standardize basic solutions for selected clusters, and leverage marketing insights. The three companies have modified their market approach and show a common orientation toward a customer-centric view. In Biesse, the single customer is given the possibility to decide about the level of customization expected around the product, which is considered a technological platform to enact innovative and increasingly efficient production processes. Concerning Bianchi, the company has a B2B portal to interact with thousands of dealers (as clients) as a new digital way to manage a mass market with a rich catalog. The e-store is the front-end, with the final customer able to create an interaction, and offers a product customized to the customer's wishes. Its supply chain today combines the efficiency represented by the "mass of dealers" and the interaction with customers through its e-store with new emerging channels like apps and social communities to be closer to the customers. Its new e-bike is sold and distributed through digital channels and offers more possible combinations of personalization along with numerous additional products. Irca $\mathrm{SpA}$, through its new platform, has extended its network of distributors and installers who provide a customer base and knowledge on the installed base, marketing analysis, direct monitoring, and predictive and customer interaction, where the relationship with suppliers is built on offering the best capacity in innovation, time to market, costs, service, and quality to ensure the greatest satisfaction of customers. Thanks to the implementation of the customer orientation, customers' relationship has become more clearness, proprietary, and cooperative through a codesign approach in order to shape the solution for each customer, the user of the solution itself.

According to the entrepreneurial model, international companies are concerned with control and market openness. In the 2nd industrial revolution, the hierarchical control over the entire company's necessary resources and processes determined the organizational must plan while the hierarchy guided the control needed to guarantee the efficiency and power over the market. Such a need for control has now shifted to data flows and all the processes and technologies necessary to guarantee their security and privacy according to the customer's view. Thus, although the company needs to maintain control over the new sources of strategic advantage (i.e., the data), this control is implemented not on an internal context but in an interconnected ecosystem. In the latter, the company should prove organizational flexibility. Biesse is a company that considers direct proprietary control over the main technologies as a competitive advantage. Despite this strategic insourcing approach, the company involves a various number of suppliers and technological partners in its innovation and internationalization processes. The challenge of the recent digital transformation 
process is mainly given by the ability to depict a flexible organizational structure capable of guaranteeing the security of the customers' data. Bianchi has developed an ecosystem (partners with several competences and expert riders) that collaborates/co-produces to create a unique and innovative product for the market (i.e., the e-bike). Today the challenge facing Bianchi is to stay in the market and face emerging competitors from the United States and Japan; therefore, it needs to maintain a balance between efficiency and R\&D. This new way to work demonstrates that the headquarters in Treviglio is able to enhance its entrepreneurial model by sharing knowledge, looking for new and advanced partners, opening close to markets, and leveraging outsourcing formulas to maintain its efficiency no matter what. Even Irca $\mathrm{SpA}$ has created a new ecosystem in order to develop a new platform based on an agreement it has with established technology partners, such as SMC, Eurotech, and Sysdata, as well as start-ups, like the one that developed the augmented reality system. Its $R \& D$ department plays a major role in the innovation process, aiming to anticipate and better serve market needs. In addition, R\&D efforts gain large benefits from synergies, competence, and know-how shared among Irca SpA through its new network of partners. The company has therefore adopted an open innovation paradigm to support group innovation aimed at accelerating innovation and digital transformation in all industrial sectors. To be efficient and effective in all company processes, the company applies the Zoppas Lean System methodologies also supported by project management techniques in order to share know-how and technical-organizational skills with all of the group's production sites. These elements affect how the companies are able to manage their international positions. All the companies born in the 2 nd industrial revolution became national leaders in their respective sectors during this period. In the 3rd industrial revolution, the companies started to establish a global presence through acquisitions and the implementation of productive plans abroad. Biesse founded subsidiaries in the United States and Dubai and a productive plant in India; Bianchi expanded its presence in the United States, Turkey, Mexico, and Australia; and Irca SpA established production facilities in Germany, Brazil, Romania, the United States, Mexico, China, and northern markets. In the 4th industrial revolution, all three companies consolidated their international physical presence while also pursuing the enhancement of their uniquely distinctive Italian manufacturing features. Biesse has created a specific training path for new human resources; as a result, as Fabio La Cava, the group HR director, said, they have the possibility "to spend 12 months working at the group's headquarters in Italy in order to acquire in-depth knowledge of the Italian business and business processes as well as go through technical training. Subsequently, trainees can gain work experience at one of the group's international locations in Europe, Asia, North America, and Australia" (Biesse Group 2019). Meanwhile, Bianchi remains focused on Italian manufacturing; all of its frames as well as the graphics and color combinations are designed and created inside its Treviglio headquarters (Bergamo) by Italian team leaders (Bianchi SpA 2019a). Irca SpA maintains the identity of its Italian headquarters in every plant abroad through the Zoppas Lean System and the Corporate Lean teams. This choice is justified by the willingness to structure and lead international teams in order to overcome cultural diversities that can be found in different countries promoting Italian manufacturing (Auxiell 2019). For example, 
after the installation of an ERP system at its headquarters in Italy, the same systems were also installed at production sites located abroad to create a uniform operating environment in order to export not only personnel and capital, but also the same operating models that have guaranteed the company's success in Italy (Banca dati Italia Lavoro 2017).

\section{Interpretative framework: matching the past and the future for gradual radical change}

Given the analysis herein and the main aim of the paper, a preliminary interpretative framework can be presented as depicted in Table 3, which details the specific issues representing the business drivers, the supply view, and the entrepreneurial model characterizing international manufacturing companies facing a digital transformation. In terms of developing these elements, Table 3 highlights the issues emerging from the previous industrial revolutions that have to be properly used and exploited, conceptualizing what is said by the literature (concepts presented in Sect. 2) and the main elements identified during the analysis of the empirical setting (specific aspects that emerged during the discussion of the cases in Sect. 3.4).

Regarding the first aspect (business driver), the 2nd industrial revolution focused on production efficiency, economy of scale, and standardization. In terms of the new technology involved, the standardization of the components is a central aspect as it is an enabler of the machines' interconnectivity throughout all processes. This interaction among machines brings a cost advantage in terms of the reduction of time and optimization of information on production because it prevents human intervention. During the machine-to-machine operations, a huge volume and variety of internal and external data are shared and delivered in real time in a number of different and novel ways. In this context, the ability to standardize the process to refine and extract value from data is fundamental through the scaling achieved by the large amount of data (i.e., Big Data). In the 4th industrial revolution, the product completely overlaps and is integrated with the service, becoming more like data platform solutions (for example, the components of smart connected products include mechanical and electrical parts, software, sensors, data storage, digital user interface, and cloud). This is the last evolution of the servitization concept that emerged in the $3^{\text {rd }}$ industrial revolution under the initial meaning of the subordination of a service compared to a product. Service is always key in engaging the customer as well as differentiating products and generating profit. In the IoT world, the use of data platforms means the ability to shape a solution for a customer as a result of product and service integration. In particular, the customers and/or partners take part in the whole process of service definition, providing constant feedback before and during the use of the service itself. A step further in the servitization process in the 4th industrial revolution is given by the focus on offering the customized use of the product/system rather than its ownership. The product/system becomes a platform that is necessary but less relevant than the consultancy and data services built around it.

Concerning the supply view, pushing the mass market to produce volumes and reduce costs and prices was the company's market approach in the 2 nd industrial 


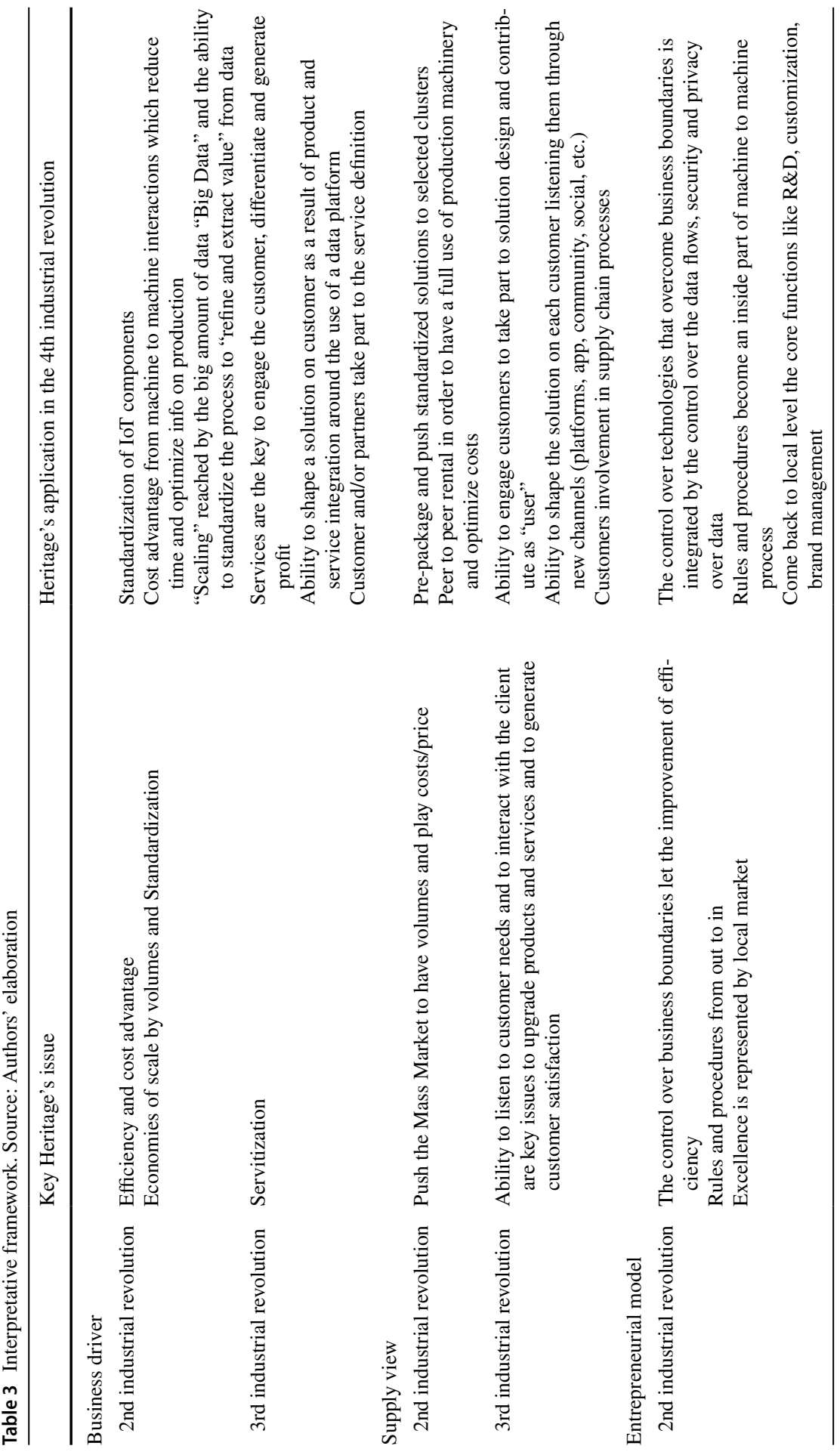




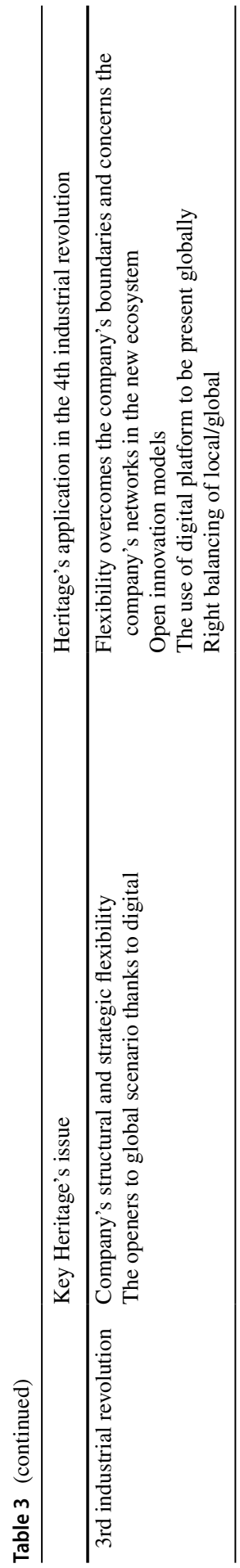


revolution. Now, based on new criteria and capabilities of market segmentation, it is possible to prepackage, standardize, and push some "basic solutions" to homogeneous clusters. These solutions can then also be opened to customization by further components or services. Peer-to-peer rental becomes an unavoidable action in order to have full usage of production machinery and the optimization of costs (Abhishek et al. 2018). With the increased variety and variability of the market during the 3rd industrial revolution, customer-driven strategies guiding the company's demand sales and operation planning are necessary, together with the need to activate and reinforce customer relationships that also view the participation of the customer to service/product development. In the 4th industrial revolution, industry boundaries have been eliminated, and the market has become increasingly complex and dynamic. The centrality of the customer is a pillar, where utilization-not ownership—of products and tight interactions between customers and the manufacturing company are essential elements. During this period, the democratization of products and process knowledge has arisen, as customers take part in the solution design and contribute as "users" of the product.

The solution is shaped for each customer thanks to the ability to understand the whole customer journey through new channels. In fact, new platforms, apps, social media, and communities allow for constant feedback that is shared throughout the entire supply chain and brings about the ongoing updating of solutions. The supply chain has changed from a traditional, vertical, and linear structure typical of the 3rd industrial revolution toward a networked one as traditional CRM evolved. Data collected and generated from the customer's side make it possible to better demand forecasting and ensure the more efficient and effective reconfiguration of supply chain processes. The customer has thus become an active part of the whole supply chain.

The third aspect is the entrepreneurship model. The 2nd industrial revolution highlighted that controlling the business boundaries improves efficiency as companies prefer to operate within the open market and protect the excellence of the products. Efficiency is also achieved through standardized rules and organizational procedures. In today's business context, thanks to their control over basic technologies, big data, and new services, new companies often go beyond traditional business boundaries and create a network of partners, without forgetting to maintain some core functions in the local market. They search for the control over the flows of data and, consequently, also guarantee security and privacy to customers. This new market context implies new rules of governance, as is particularly evident considering all the new regulations related to the privacy, protection, and security of data. Regarding machine-to-machine interactions, the rules and procedures have become an inherent feature due to the self-monitoring of the process. Since the 3rd industrial revolution, a fundamental concept that has remained is the structural and strategic flexibility of manufacturing companies. In fact, the present industrial revolution highlights that activities are streamlined in a number of new ways, and repercussions occur in terms of integration and connectivity. The rivalry is no longer company versus company or traditional supply chain versus traditional supply chain, but rather supply network versus supply network. Flexibility is still one of the key attributes in the 4th industrial revolution for ensuring that manufacturing companies 
can better manage networked companies in an ecosystem and related business models. In this context, the outsourcing of processes and activities to partners involved in the ecosystem is a reaction to the efficiency and flexibility needs, bringing with it an open innovation model. In other words, they must be able to correctly mix global and local presences, clearly defining where the core competences are.

\section{Conclusion}

This paper analyzes the ongoing processes of digital transformation in manufacturing SMEs which have a long time business history. We have underlined how since their birth during the second industrial revolution such companies have developed and grown being capable to absorb and adapt themselves to the different technological and business contexts. The present digital transformation they are facing is not a totally disruptive process. Differently we stress that the companies leverage on the lessons they have experienced and learned during the 2nd and 3rd industrial revolutions. We highlight the fact that, in successful manufacturing companies, a gradual radical change represents a winning approach to face changes demanded by new technological and competitive pressure.

We have developed an interpretative framework that shows which main lessons provided by the 2 nd and, especially, by the 3rd industrial revolutions are primary values to transfer in the company's digital transformation in order to implement it efficiently and effectively creating new opportunities for manufacturing SMEs in an international landscape. Looking at what was emerged by our research, today's international SMEs should proceed for a gradual radical change's approach leveraging on the transformation process already started in the past, despite a stress on discontinuity based on the concept of digital disruption. This consideration emerges from the present study and improves existing literature on the theme of innovations (in particular digital technologies in the new context of Industry 4.0), supporting the debate of academics on gradual vs. radical changes.

It means, as implication for managers, that approaching digital transformation it's not matter to disregard the past and to start from scratch, but to reinterpret some evergreen concepts like efficiency, performance, competitiveness, productivity, globalization with new glasses enabled by the new technologies. We observed in the three cases that their international success has been led by the ability to mix and balance tradition and innovation, local and global. Business drivers, supply chain and entrepreneurial model are aspects that, if correctly analyzed, could provide insights for better exploration of todays' companies. In particular, according to business driver, a company that operates in the actual environment should stem from concept like efficiency, cost advantage, economy of scales and standardization in order to take into account that these are the basis of operations for IoT components, Big Data and machine to machine interactions. In addition, the servitization issue is a core element when companies approach customers. According to supply view, a company should consider heritages as pushing the mass market and listening the customer in order to better involve customer in the supply chain processes. Finally, according to entrepreneurial model, managers should consider business boundaries, rules and 
procedures, local/global balance and flexibility in order to allow their companies to correctly act in the new ecosystem.

We are aware that our research is at an early exploratory stage and it refers to a limited number of selected case studies. The work should be improved developing a survey extended to both Italian and international manufacturing SMEs. Moreover, it should be important to consider manufacturing companies maybe clustered for typology of industry and a comparison with non-manufacturing companies could be conducted though further studies.

Funding Open access funding provided by Università Cattolica del Sacro Cuore within the CRUI-CARE Agreement.

Open Access This article is licensed under a Creative Commons Attribution 4.0 International License, which permits use, sharing, adaptation, distribution and reproduction in any medium or format, as long as you give appropriate credit to the original author(s) and the source, provide a link to the Creative Commons licence, and indicate if changes were made. The images or other third party material in this article are included in the article's Creative Commons licence, unless indicated otherwise in a credit line to the material. If material is not included in the article's Creative Commons licence and your intended use is not permitted by statutory regulation or exceeds the permitted use, you will need to obtain permission directly from the copyright holder. To view a copy of this licence, visit http://creativecommons.org/licen ses/by/4.0/.

\section{References}

Abernathy, W. J., \& Utterback, J. M. (1978). Patterns of industrial innovation. Technology Review, 80(7), 40-47.

Abhishek, V., Guajardo, J., \& Zhang, Z. (2018). Business models in the sharing economy: Manufacturing durable goods in the presence of peer-to-peer rental markets. Working Paper.

Accenture. (2018). Biesse Group IoT builds new reveneu streams. Retrieved December 7, 2018, from https://www.accenture.com/ro-en/success-biesse-group-iiot-builds-new-revenue-streams.

Achrol, R. A., \& Kotler, P. (1999). Marketing in the network economy. Journal of Marketing, 63, $146-163$.

Anderson, C. (2012). Makers: The new industrial revolution. New York: Crown Business.

Auxiell. (2019). Esempio Casi. Retrieved from https://www.auxiell.com/esempi-creati/zoppas-industries /.

Baldwin, C. Y., \& Clark, K. B. (1997). Managing in an age of modularity. Harvard Business Review, 75(5), 84-93.

Banca dati Italia Lavoro. (2017). Banca dati Italia Lavoro. Retrieved March 5, 2019, from https://banca dati.italialavoro.it/bdds/download?fileName=C_21_Strumento_885_documenti_itemName_0_ documento.pdf\&uid=88ad6d54-72e5-41bf-bd8d-758aba0f1a71.

Baskin, K. (1995). DNA for corporations: Organizations learn to adapt or die. The Futurist, 21(1), 68.

Baskin, K. (2012). Corporate DNA. London: Routledge.

Beltrametti, L., Guarnacci, N., Intini, N., \& La Forgia, C. (2017). La fabbrica connessa. La manifattura italiana (attra)verso Industria 4.0. Guerini Associati.

Berger, R. (2014). Industry 4.0-The new industrial revolution-How Europe will succeed. (R. B. S. Consultants, Ed.).

Berman, S. (2012). Digital transformation: opportunities to create new business models. Strategy \& Leadership, 40(2), 16-24.

Bianchi SpA. (2018). Business history. Retrieved November 6, 2018, from https://www.bianchiusa.com/ history/. 
Bianchi SpA. (2019a). Bianchi Corporate. Retrieved March 6, 2019, from https://www.bianchi.com/it/ bianchi/corporate_bianchi.aspx.

Bianchi SpA. (2019b). The Bianchi Magazine 2020, 1-97. Retrieved from https://www.bianchi.com/wpcontent/uploads/2019/11/Magazine_EN_IT.pdf.

Biesse Group. (2012). Technology for shaping everyday materials. Retrieved from https://www.biess egroup.com/media/files/148_evento_star_milano_27-28_marzo_2012.pdf.

Biesse Group. (2018). Company story. Retrieved March 4, 2019, from https://www.biessegroup.com/en/.

Biesse Group. (2019). Internationalisation the key to building the future. Retrieved March 5, 2019, from https://www.biessegroup.com/en/magazine/internationalisationthe_key_to_building_the_future.

BikeType. (2018). Bianchi. Retrieved November 17, 2018, from https://biketype.com/pages/2961/bianc hi.

Bogers, M., Hadar, R., \& Bilberg, A. (2016). Additive manufacturing for consumer-centric business models: Implications for supply chains in consumer goods manufacturing. Technological Forecasting and Social Change, 102, 225-239. https://doi.org/10.1016/j.techfore.2015.07.024

Bonchek, M. (2016). How to discover your company's DNA. Harvard Business Review. Retrieved November 3, 2018 from https://hbr.org/2016/12/how-to-discover-your-companys-dna.

Brynjolfsson, E., \& McAfee, A. (2016). The second machine age: Work, progress and prosperity in a time of brilliant technologies. New York: Norton \& Company.

Christopher, M. (2016). Logistics \& supply chain management. London: Pearson Higher Education.

Coltorti, F., Resciniti, R., Tunisini, A., \& Varaldo, R. (2013). Mid-sized manufacturing companies: The new driver of Italian competitiveness. Milan: Springer Science \& Business Media.

Cook, T. D., \& Campbell, D. T. (1979). Quasi-experimentation: Design and analysis for field settings. Chicago: Rand McNally.

Cyclist. (2015). Bianchi: Factory visit. Retrieved November 3, 2018, from https://www.cyclist.co.uk/bianc hi/493/bianchi-factory-visit.

Downes, L., \& Nunes, P. (2015). Big Bang disruption. L'era dell'innovazione devastante: Penguin Books Limited.

Electrolux Global Brand Licensing. (2018). Zoppas. Retrieved November 28, 2018, from https://brandlicen sing.electrolux.com/en/our-brands/all/zoppas/.

Ellram, L. M. (1996). The use of the case study method in logistics research. Journal of Business Logistics, 17(2), 93-138. https://search.ebscohost.com/login.aspx?direct=true\&db=buh\&AN=9706191110 $\&$ site $=$ ehost-live.

EpicCycles. (2018). Epic Cycles_-The UK's leading quality bike store. Retrieved November 5, 2018, from https://epic-cycles.co.uk/page/12?post_type=product\&product_orderby=price\&product_view=list.

Fawcett, S. E., Waller, M. A., Miller, J. W., Schwieterman, M. A., Hazen, B. T., \& Overstreet, R. E. (2014). A trail guide to publishing success: Tips on writing influential conceptual, qualitative, and survey research. Journal of Business Logistics, 35(1), 1-16.

Felin, T., \& Foss, N. J. (2009). Organizational routines and capabilities: Historical drift and a course-correction toward microfoundations. Scandinavian Journal of Management, 25(2), 157-167.

Forbes. (2018). Company values and DNA the differences that make us special. Retrieved March 3, 2019, from https://www.forbes.com/sites/forbeshumanresourcescouncil/2018/07/31/company-values-anddna-the-differences-that-make-us-special/\#527da99e57e7.

Gallivan, M. J., Hofman, J. D., \& Orlikowski, W. J. (1994). Implementing radical change: Gradual versus rapid pace. In Proceedings of the fifteenthinternational conference on information systems, Vancouver, British Columbia, Canada, December 14-17 (pp. 325-339).

Gibbert, M., Ruigrok, W., \& Wicki, B. (2008). What passes as a rigorous case study? Strategic Management Journal, 29(13), 1465-1474.

Herbert, L. (2017). Digital transformation: Build your organization's future for the innovation age. London: Bloomsbury Publishing.

Hines, T. (2012). Supply chain strategies. Customer driven and customer focus. Abingdon: Routledge.

IGS Connect. (2017). Digital DNA qual è quello della tua impresa. Retrieved March 1, 2019, from https:// www.igsconnect.com/digital-dna-qual-quello-della-tua-impresa/.

Kagermann, H. (2015). Change through digitization-value creation in the age of industry 4.0. In H. Albach, H. Meffert, A. Pinkwart, \& R. Reichwald (Eds.), Management of permanent change. Wiesbaden: Springer Gabler.

Kransdorf, A. (2017). Corporate DNA: Using organizational memory to improve poor decision-making. Abingdon: Routledge. 
Lamming, R. (1993). Beyond partnership: strategies for innovation and lean supply. New York: Prentice Hall.

Lillis, A. M., \& Mundy, J. (2005). Cross-sectional field studies in management accounting research-Closing the gaps between surveys and case studies. Journal of Management Accounting Research, 17(1), 119-141.

Madeinitaly.org. (2019). Made in Italy. Retrieved February 15, 2019, from https://madeinitaly.org/en/madein-italy/made-in-italy.php.

Matt, C., Hess, T., \& Benlian, A. (2015). Digital transformation strategies. Business \& Information Systems Engineering, 57(5), 339-343.

McQuivey, J., \& Bernoff, J. (2013). Digital disruption: Unleashing the next wave of innovation. Las Vegas, NV: Amazon Publishing.

Mediobanca. (2020). Medie imprese italiane e nuove tecnologie: una distanza da colmare, Ufficio Studi Mediobanca. Retrieved February 25, 2020 fromhttp://www.mbres.it/sites/default/files/resources/downl oad_it/Barbaresco\%20-\%20Milano\%207\%20febbraio\%202020.pdf.

01Net. (2018). Zoppas Connettendo, piattaforma IoT per il B2B. Retrieved November 30, 2018, from https:// www.01net.it/zoppas-connettendo-iot-b2b/.

Patton, M. Q. (1990). Qualitative evaluation and research methods. Los Angeles: SAGE Publications Inc.

Porter, M. E., \& Heppelmann, J. E. (2014). How smart, connected products are transforming competition. Harvard Business Review, 92(11), 64-88.

Porter, M. E., \& Heppelmann, J. E. (2015). How smart, connected products are transforming companies. Harvard Business Review, 93(10), 96-114.

Potter, A., Towill, D. R., \& Christopher, M. (2015). Evolution of the migratory supply chain model. Supply Chain Management: An International Journal, 20(6), 603-612. https://doi.org/10.1108/ SCM-06-2015-0231

Ridder, H. G. (2017). The theory contribution of case study research designs. Business Research, 10(2), 281-305.

Rogers, H., Baricz, N., \& Pawar, K. S. (2016). 3D printing services: classification, supply chain implications and research agenda. International Journal of Physical Distribution \& Logistics Management, 40(10), 886-907.

Sanchez, R., \& Mahoney, J. T. (1996). Modularity, flexibility, and knowledge management in product and organization design. Strategic Management Journal, 17(S2), 63-76.

Schwab, K. (2017). The fourth industrial revolution. New York: Crown Business.

Siebel, T. M. (2018). Why digital transformation is now on the CEO's shoulders. Retrieved December 9, 2018, from https://www.mckinsey.com/business-functions/digital-mckinsey/our-insights/why-digitaltransformation-is-now-on-the-ceos-shoulders\%0D.

Siebel, T. M. (2019). Digital transformation: Survive and thrive in an era of mass extinction. New York: RosettaBooks.

SMC, \& Zoppas Industries. (2018). Zoppas Industries: strategie di innovazione per la domotica e l'Industria 4.0. Retrieved 29 November 2018, from https://www.smau.it/milano17/success_stories/zoppas-indus tries-strategie-di-innovazione-per-la-domotica-e-lindustria-40/.

Stevens, G. C., \& Johnson, M. (2016). Integrating the supply chain ... 25 years on. International Journal of Physical Distribution \& Logistics Management, 46(1), 19-42. https://doi.org/10.1108/IJPDL M-07-2015-0175

Syam, N. B., \& Pazgal, A. (2013). Co-creation with production externalities. Marketing Science, 32(5), 805-820.

Sysdata. (2018). Zoppas Industries: Hot, App \& Cloud. Retrieved November 29, 2018, from https://www. sysdata.it/casi-di-studio/zoppas-industries/.

Teece, D. J., Pisano, G., \& Shuen, A. (1997). Dynamic capabilities and strategic management. Strategic Management Journal, 18(7), 509-533.

Tushman, M. L., \& Anderson, P. (1986). Technological discontinuities and organizational environments. Administrative Science Quarterly, 31, 439-465.

Uhl, A., \& Gollenia, L. A. (2014). Digital enterprise transformation. Abingdon: Routledge.

Varaldo, R., Dalli, D., Resciniti, R., \& Tunisini, A. (2009). Un tesoro emergente: Le medie imprese italiane dell'era globale. Milano: Franco Angeli.

Varaldo, R., \& Ferrucci, L. (1996). The evolutionary nature of the firm within industrial districts. European Planning Studies, 4(1), 27-34.

Vergne, J. P., \& Durand, R. (2011). The path of most persistence: An evolutionary perspective on path dependence and dynamic capabilities. Organization Studies, 32(3), 365-382. 
Womack, J. P., Jones, D. T., \& Roos, D. (1990). Machine that changed the world. (Simon and Schuster, Ed.). Yin, R. K. (1984). Case study research: Design and methods. Beverly Hills, Calif: Sage Publications.

Yin, R. K. (1989). Research design issues in using the case study method to study management information systems. The Information Systems Research Challenge: Qualitative Research Methods, 1, 1-6.

Yin, R. K. (2003). Designing case studies. Qualitative research methods, 359-386.

Yin, R. K. (2013). Validity and generalization in future case study evaluations. Evaluation, 19(3), 321-332. https://doi.org/10.1177/1356389013497081

Zack, M. H. (1999). Developing a knowledge Strategy. California Management Review, 41(3), 125-145.

Zoppas Industries. (2017). Zoppas compete nel mondo con i robot. Retrieved from https://www.ansa.it/indus try_4_0/notizie/interviste/2017/10/20/zoppas-compete-nel-mondo-con-i-robot_e95f9a4f-9c82-4e09b8d7-c8a246986d34.html.

Zoppas Industries. (2018a). Quality. Retrieved November 30, 2018, from https://www.zoppasindustries.com/ en/quality/.

Zoppas Industries. (2018b). Research and development. Retrieved November 28, 2018, from https://www. zoppasindustries.com/en/rd/.

Publisher's Note Springer Nature remains neutral with regard to jurisdictional claims in published maps and institutional affiliations.

\section{Affiliations}

\section{Elisa Martina Martinelli ${ }^{1}$ D $\cdot$ Maria Cristina Farioli ${ }^{1} \cdot$ Annalisa Tunisini $^{1}$}

Maria Cristina Farioli

mariacristina.farioli@unicatt.it

Annalisa Tunisini

annalisa.tunisini@unicatt.it

1 Catholic University of the Sacred Heart, Milan, Italy 